\title{
ANALISIS EFISIENSI USAHATANI PADI DI JAWA DAN LUAR JAWA, KAJIAN PROSPEK PENINGKATAN PRODUKSI PADI NASIONAL
}

\author{
$\underline{\text { Rivani Hilalullaily }{ }^{1} \text {, Nunung Kusnadi }{ }^{2} \text {, dan Dwi Rachmina }{ }^{3}}$ \\ 1)Program Magister Sains Agribisnis, Sekolah Pascasarjana, Institut Pertanian Bogor \\ 2,3)Departemen Agribisnis, Fakultas Ekonomi dan Manajemen, Institut Pertanian Bogor \\ Jl. Kamper Wing 4 Level 5 Kampus IPB Dramaga, Indonesia \\ e-mail: 1)rivani_13@apps.ipb.ac.id
}

(Diterima 6 Agustus 2020/Revisi 14 Agustus 2020/Disetujui 1 September 2020)

\begin{abstract}
Rice can grow in almost all of the islands in Indonesia, but 57 per cent of it was produced in Java, which is less than 10 per cent of the national area in Indonesia. To anticipate the increasing need for rice consumption, it is important to study the prospects for increasing national rice production, especially by utilizing the potential of agricultural land outside Java island. The purpose of this study was to identify the prospects for the development of national rice, especially outside Java island, from the perspective of rice production factors and technical efficiency at the farm level. Using stochastic frontier analysis, the translog production function showed that the increasing use of inputs (land, seeds, fertilizers, pesticides) will not significantly increase rice production both in Java and outside Java island (inelastic). Technical efficiency analysis indicated that rice production in Java and outside Java island was 28 and 39 per cent below its frontier, respectively. Further analysis showed that irrigation, land status, farmer groups, and farmer education were significantly improved technical efficiency. This study concluded that the potential to increase rice production by increasing technical efficiency outside of Java island was greater than in Java island. However, increasing the efficiency of rice production outside Java may be constrained by the availability of irrigated agricultural land. To significantly increase national rice production both in Java and outside Java island, a breakthrough in new rice production technology is needed.
\end{abstract}

Keywords: elasticity, irrigation, technical efficiency, translog model

\begin{abstract}
ABSTRAK
Padi dapat tumbuh di hampir seluruh pulau di Indonesia, tetapi 57 persen padi di produksi di Pulau Jawa (BPS 2019b), dengan luasan kurang dari 10 persen dari total luasan di Indonesia (BPS 2019a). Studi mengenai prospek peningkatan produksi padi nasional penting dilakukan sebagai antisipasi meningkatnya konsumsi beras, terkhusus dengan memanfaatkan lahan di luar Pulau Jawa. Tujuan penelitian ini yaitumengidentifikasi prospek peningkatan produksi beras nasional, terutama di luar Jawa, dari perspektif faktor produksi padi dan efisiensin teknis ditingkat petani. Dengan menggunakan stochastic frontier, fungsi produksi translog menunjukan bahwa peningkatan input (lahan, benih, pupuk dan pestisida) tidak banyak meningkatkan produksi padi di Pulau Jawa dan luar Pulau Jawa (inelastis), sedangkan tenaga kerja bertanda negatif. Berdasarkan hasil efisiensi teknis, potensi petani untuk meningkatkan produksi padi di Jawa dan luar Jawa sebesar 28 dan 39 persen. Selain itu, analisis menunjukan irigasi, status lahan, kelompok tani dan pendidikan petani memengaruhi efisiensi teknis. Penelitian ini dapat disimpukan bahwa prospek peningkatkan produksi padi dengan efisiensi teknis di luar Pulau Jawa lebih tinggi daripada di Pulau Jawa. Namun, peningkatan produksi padi di luar Pulau Jawa dapat dilakukan dengan membangun lahan irigasi. Selain itu, untuk meningkatkan produksi padi secara signifikan diperlukannya teknologi produksi padi baru baik di Jawa dan luar Jawa.
\end{abstract}

Kata kunci: elastisitas, efisiensi teknis, irigasi, model translog 


\section{PENDAHULUAN}

Beras berperan penting dalam perekonomian Indonesia karena hingga saat ini beras menjadi makanan pokok di Indonesia. Beras merupakan hasil komoditas pangan yang paling banyak dikonsumsi oleh masyarakat dibanding komoditas pangan lainnya (BPS 2018) dan konsumsinya akan terus bertambah seiring dengan penambahan jumlah penduduk di Indonesia. Hasil sensus penduduk yang dilakukan oleh BPS (2019a) menunjukan bahwa laju pertumbuhan penduduk dari tahun 2011 sampai 2017 sebesar 8,22 persen, diikuti dengan konsumsi beras juga meningkat dengan laju pertumbuhan konsumsi beras sebesar 4,81 persen (BPS 2017). Konsumsi yang meningkat apabila tidak diikuti dengan peningkatan produksi akan mengakibatkan tidak tercukupinya kebutuhan beras nasional. Oleh karena itu, upaya peningkatan produksi padi (supply side) penting untuk dilakukan.

Data BPS (2019b) menunjukan penurunan produksi padi terjadi sebesar 7,76 persen pada tahun 2019 dibandingkan tahun 2018. Penurunan produksi disebabkan oleh penurunan luas lahan (6,15 persen) dan produktivitas (7,60 persen). Di samping itu, produksi padi masih terpusat di Jawa. Pulau Jawa menyumbang produksi padi nasional sebesar 57 persen (BPS 2019b), padahal luasan wilayahnya kurang dari 10 persen dari total wilayah di Indonesia (BPS 2019a). Produktivitas padi di Jawa (57 persen) lebih besar dibandingkan di luar Jawa (43 persen). Salah satu penyebabnya yaitu jumlah lahan irigasi di Jawa sebesar 51 persen, lebih banyak dibandingkan di luar Jawa sebesar 49 persen (Pusdatin 2018). Selain itu secara agroekosistem, lahan di Jawa lebih banyak yang sesuai (S1 dan S2) untuk produksi padi dibandingkan di luar Jawa (Widiatmaka 2016)

Peningkatan produksi dengan ekstensifikasi di Jawa akan semakin sulit untuk dilakukan. Selain itu, di Jawa terjadi peningkatan konversi lahan seperti lahan produksi padi dan jaringan irigasi. Konversi lahan sawah terjadi sebesar 96 ribu ha/tahun (Mulyani et al. 2016). Penduduk di Jawa yang sangat padat dan makin tingginya kompetisi penggunaan lahan menjadi penyebab terjadinya konversi lahan tersebut. Data BPS (2019a) menunjukkan jumlah penduduk di Jawa sebesar 56 persen dari total penduduk di Indonesia, sedangkan luas wilayahnya hanya 6,74 persen dari wilayah Indonesia. Konversi lahan mengakibatkan luas lahan pertanian menurun, termasuk areal padi. Hal ini mengakibatkan luas panen padi berkurang sebesar 6,15 persen pada tahun 2018 - 2019 (BPS 2019b).

Melihat kondisi yang terjadi di Jawa, maka peningkatan produksi diarahkan pada perluasan areal produksi di luar Jawa dengan memanfaatkan lahan terlantar, lahan kawasan transmigrasi dan lahan pertanian Daerah Aliran Sungai (DAS) Hulu. Di luar Jawa tersedia potensi lahan untuk perluasan areal pertanian di lahan basah pada tahun 2015 sebesar 7,3 juta ha (Mulyani 2017). Luasan tersebut cukup besar untuk peningkatan produksi padi nasional.

Berdasarkan permasalahan tersebut, maka dalam rangka mengantisipasi konsumsi beras yang terus meningkat, perlu dianalisis prospek peningkatan produksi padi di wilayah Jawa dan luar Jawa. Prospek tersebut dapat dianalisis menggunakan fungsi produksi dan efisiensi teknis. Tujuan studi ini yaitu untuk menganalisis potensi peningkatan produksi padi dengan menganalisis faktor-faktor yang memengaruhi produksi, mengukur efisiensi teknis dan menganalisis faktor-faktor yang memengaruhi efisiensi teknis usahatani padi di Pulau Jawa dan di luar Pulau Jawa.

\section{METODE}

\section{DATA DAN SUMBER DATA}

Data sekunder digunakan dalam penelitian ini, data tersebut berasal dari hasil survei ST2013 subsektor rumah tangga usaha tanaman padi yang dilaksanakan oleh Badan Pusat Statistik (BPS). Data tersebut berupa data usahatani padi di enam provinsi yaitu Pulau Jawa meliputi Provinsi Jawa Barat, Jawa Tengah, dan Jawa Timur, di luar Pulau 
Jawa meliputi Provinsi Sumatera Utara, Sulawesi Selatan dan Kalimantan Selatan. Lokasi dipilih karena wilayah tersebut merupakan sentra produksi padi yang mewakili pulau-pulau besar di Indonesia (BPS 2018). Jumlah provinsi yang menjadi sampel sama antara Jawa dan luar Jawa yaitu masing-masing tiga provinsi. Hal tersebut dipilih karena luas panen di Pulau Jawa dan luar Pulau Jawa hampir sama yaitu 50 persen. Jumlah usahatani sampel di Pulau Jawa sebanyak 4.755 petani dan luar Jawa sebanyak 1.949 petani. Jenis data yang digunakan berupa data kuantitatif seperti lahan, benih, pupuk, tenaga kerja, pestisida dan akses kredit, selain itu digunakan juga data kualitatif seperti status pendidikan, irigasi, kelompok tani, penyuluhan, bantuan usahatani dan wilayah.

\section{ANALISIS DATA}

Prospek peningkatan produksi padi nasional, dianalisis dari sisi teknologi produksi dan efisiensi teknis. Fungsi produksi dan efisiensi teknis dengan stochastic frontier. Analisis fungsi produksi untuk mengukur respon produksi terhadap penggunaan input. Efisiensi teknis stochastic frontier dapat menganalisis prospek peningkatan produksi padi dengan melihat gap (inefficiency) dari produksi aktual dengan produksi frontiernya. Semakin tinggi gap tersebut, maka semakin besar prospek usahatani untuk mencapai produksi padi yang maksimal (frontier).

Benih, pupuk, tenaga kerja dan pestisida diduga memengaruhi fungsi produksi. Variabel pupuk yang dipakai oleh petani yaitu pupuk urea, TSP/SP36, ZA, dan NPK. Akan tetapi, tidak semua petani padi di Indonesia memakai pupuk secara lengkap, maka jenis pupuk disisih berdasarkan kandungan zat aktifnya yaitu pupuk Nitrogen (N) yang dikonversi dari pupuk urea, pupuk ZA dan pupuk NPK, sedangkan pupuk Phospor (P) di konversi dari pupuk TSP/SP-36 dan pupuk NPK. Berikut adalah konversi pupuk $\mathrm{N}$ dan pupuk $P$ yaitu:
Pupuk $N=(0.46 \times$ pupuk urea $)+(0.208 \times$ pupuk ZA $)+(0.15 \times$ pupuk NPK $)$

Pupuk $\mathrm{P}=(0.36 \times$ pupuk SP-36 $)+(0.15 \times$ pupuk NPK)

Analisis penelitian ini menggunakan fungsi produksi translog yang pertama digagas oleh Christensen et al. (1973). Persamaan model fungsi produksi translog dalam penelitian ini sebagai berikut:

$$
\begin{aligned}
& \operatorname{Ln} Y=\beta_{0}+\beta_{1} \ln x_{1}+\beta_{2} \ln x_{2}+\beta_{3} \ln x_{3}+\beta_{4} \ln x_{4}+ \\
& \beta_{5} \ln x_{5}+\beta_{6} \ln x_{6}+\frac{1}{2} \beta_{11} \ln x_{1}^{2}+\beta_{12} \ln x_{1} \ln x_{2} \\
& +\beta_{13} \ln x_{1} \ln x_{3}+\beta_{14} \ln x_{1} \ln x_{4}+\beta_{15} \ln x_{1} \ln x_{5} \\
& +\beta_{16} \ln x_{1} \ln x_{6}+\frac{1}{2} \beta_{22} \ln x_{2}^{2}+\beta_{23} \ln x_{2} \ln x_{3}+ \\
& \beta_{24} \ln x_{2} \ln x_{4}+\beta_{25} \ln x_{2} \ln x_{5}+\beta_{26} \ln x_{2} \ln x_{6}+ \\
& \frac{1}{2} \beta_{33} \ln x_{3}^{2}+\beta_{34} \ln x_{3} \ln x_{4}+\beta_{35} \ln x_{3} \ln x_{5}+ \\
& \beta_{36} \ln x_{3} \ln x_{6}+\frac{1}{2} \beta_{44} \ln x_{4}^{2}+\beta_{45} \ln x_{4} \ln x_{5}+ \\
& \beta_{46} \ln x_{4} \ln x_{6}+\frac{1}{2} \beta_{55} \ln x_{5}^{2}+\beta_{56} \ln x_{5} \ln x_{6}+\frac{1}{2} \\
& \beta_{66} \ln \mathrm{x}_{6}{ }^{2}+\mathrm{v}_{\mathrm{i}}-\mathrm{u}_{\mathrm{i}}
\end{aligned}
$$

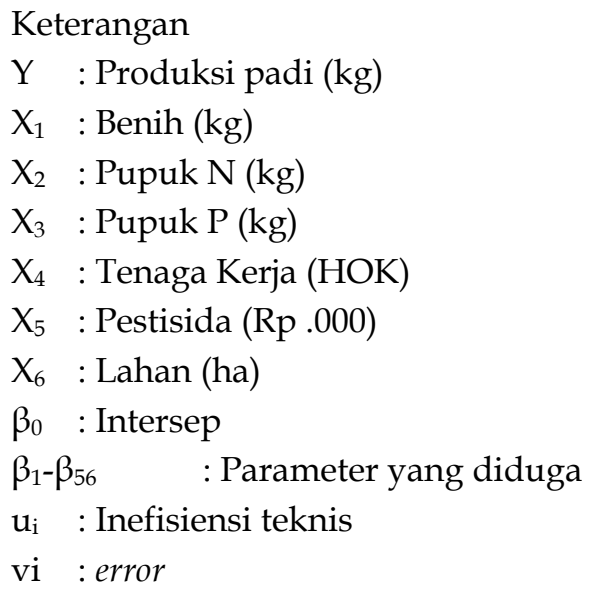

Dari model fungsi produksi translog tersebut (1) dapat diturunkan elastisitas faktor produksi, baik di Jawa dan luar Jawa menggunakan persamaan berikut:

$\frac{\partial \ln y}{\partial \ln x_{i}}=\beta_{i}+\sum_{j=1}^{n} \beta_{i j} \ln x_{j}$

Tingkat efisiensi produksi padi berdasarkan wilayah produksi (Jawa dan luar Jawa) dapat dihitung dengan menggunakan rumus berikut (Coelli et al. 2005). 
$\mathrm{TEi}=\exp (-\mathrm{E}[\mathrm{ui} \mid \varepsilon \mathrm{i}]) \mathrm{i}=1,2,3, \ldots ., \mathrm{N}$.

Keterangan:

TEi $=$ efisiensi teknis petani ke- $\mathrm{i}$

$\exp (-\mathrm{E}[\mathrm{ui} \mid \varepsilon \mathrm{i}])=$ dugaan produksi frontier yang diperoleh dari produksi stochastic frontier

Nilai koefisien efisiensi teknis yaitu antara nol sampai satu $(0 \leq \mathrm{TE} \leq 1)$ dan hanya tipe data cross section yang dapat digunakan. Nilai efisiensi teknis berhubungan negatif dengan nilai inefisiensi teknis (Coelli et al. 2005). Penetapan nilai parameter distribusi faktor inefisiensi teknis produksi padi menggunakan persamaan berikut:

$u i=\delta_{0}+\delta_{1} Z_{1}+\delta_{2} Z_{2}+\delta_{3} Z_{3}+\delta_{4} Z_{4}+\delta_{5} Z_{5}+\delta_{6} Z_{6}+$ $\delta_{7} Z_{7}+\delta_{8} Z_{8}+v i$.

Keterangan:

$u i=$ efek inefisiensi teknis

$\mathrm{Z}_{1}=$ Status pendidikan (1: tidak tamat SD sampai 8: tamat S2/S3)

$\mathrm{Z}_{2}=$ Kredit $(\%)$

$Z_{3}=$ Dummy irigasi (1= ada, $0=$ tidak ada)

$\mathrm{Z}_{4}=$ Dummy status lahan (1= milik sendiri, $0=$ sewa)

$\mathrm{Z}_{5}=$ Dummy penyuluhan $(1=\mathrm{ikut}, 0=$ tidak ikut)

$\mathrm{Z}_{6}=$ Dummy kelompok tani (1= gabung, $0=$ tidak gabung)

$\mathrm{Z}_{7}=$ Dummy bantuan pemerintah (1= dapat, $0=$ tidak dapat)

$\mathrm{Z}_{8}=$ Dummy wilayah (1= Jawa, $0=$ Luar Jawa)

$v i=$ variabel acak
Nilai koefisien yang diharapkan adalah $\delta 1, \delta 2, \delta 3, \delta 4, \delta 5, \delta 6, \delta 7, \delta 8<0$ (berpengaruh negatif terhadap inefisiensi atau positif terhadap efisiensi usahatani). Hasil pendugaan variabel dummy yang negatif $(\delta \mathbf{i}<0)$ artinya variabel dummy 1 berpengaruh negatif terhadap efek inefisiensi atau berpengaruh positif terhadap efek efisiensi teknis usahatani padi.

\section{HASIL DAN PEMBAHASAN}

\section{DESKRIPSI STATISTIK FAKTOR PRODUKSI PADI}

Wilayah Jawa dan luar Jawa memiliki karakteristik yang berbeda antar keduanya berdasarkan karakteristik usahatani padi. Pulau Jawa berperan lebih besar dalam ketersediaan beras nasional (Tabel 1). Hal ini ditunjukan dengan rata-rata produktivitas di Pulau Jawa $(4.849,45 \mathrm{~kg} / \mathrm{ha})$ yang lebih besar dibandingkan di luar Jawa $(3.566,63 \mathrm{~kg} / \mathrm{ha})$.

Pada Tabel 1 menunjukan bahwa petani di Pulau Jawa menggunakan rata-rata input (benih, pupuk $\mathrm{N}$, pupuk $\mathrm{P}$, tenaga kerja) per hektar lebih banyak dibandingkan di luar Jawa. Disamping itu, sebagian besar petani di Pulau Jawa menggunakan lahan sempit $(<0.5$ ha), sedangkan petani di luar Pulau Jawa menggunakan lahan lebih luas (>0.5 ha). Hal tersebut menunjukan bahwa petani di Pulau Jawa merupakan petani gurem.

Pemerintah merekomendasikan penggunaan benih padi sebanyak $25 \mathrm{~kg} /$ ha. Melihat hal tersebut artinya petani di Pulau Jawa dan luar Pulau Jawa menggunakan benih melam-

Tabel 1. Rata-rata, Maksimum dan Minimum Produksi, Produktivitas, dan Penggunaan Input Usahatani Padi di Pulau Jawa dan Luar Pulau Jawa

\begin{tabular}{lrrrrrr}
\hline \multirow{2}{*}{ Variabel } & \multicolumn{3}{c}{ Jawa } & \multicolumn{3}{c}{ Luar Jawa } \\
\cline { 2 - 7 } & Rata-rata & \multicolumn{1}{c}{ Min } & \multicolumn{1}{c}{ Maks } & Rata-rata & \multicolumn{1}{c}{ Min } & \multicolumn{1}{c}{ Maks } \\
\hline Produksi (kg) & $1.503,33$ & 30,00 & $33.000,00$ & $1.854,65$ & 100,00 & $20.000,00$ \\
Produktivitas (kg/ha) & $4.849,45$ & $1.500,00$ & $5.500,00$ & $3.566,63$ & $3.333,33$ & $3.991,22$ \\
Benih (kg/ha) & 46,97 & 50,00 & 80,00 & 46,00 & 26,67 & 39,91 \\
Pupuk N (kg/ha) & 123,16 & 7,50 & 184,20 & 69,29 & 5,00 & 82,68 \\
Pupuk P (kg/ha) & 3,35 & 7,50 & 0,72 & 1,83 & 5,00 & 0,89 \\
Tenaga Kerja (HOK/ha) & 17,58 & 50,00 & 7,67 & 15,54 & 33,33 & 22,55 \\
Pestisida (Rp .000/ha) & 248,23 & 0,70 & 313,00 & 262,15 & 1,33 & 393,77 \\
Lahan (ha) & 0,31 & 0,02 & 6,00 & 0,52 & 0,03 & 5,01 \\
\hline
\end{tabular}


paui rekomendasi pemerintah. Hal ini diduga karena beberapa petani menggunakan benih padi tidak bersertifikat, sehingga membutuhkan benih yang banyak. Selain itu, pemerintah juga merekomendasikan penggunaan pupuk $\mathrm{N}$ sebanyak $170 \mathrm{~kg} / \mathrm{ha}$ dengan teknologi konvensional (Permentan 2007). Artinya, ratarata petani menggunakan pupuk $\mathrm{N}$ kurang dari rekomendasi pemerintah.

\section{ANALISIS FUNGSI PRODUKSI PADI}

Aplikasi input-input produksi seperti lahan, benih, pupuk, tenaga kerja dan pestisida menentukan produksi padi. Fungsi produksi translog digunakan dalam analisis fungsi produksi (Persamaan 3). Hasil pendugaan fungsi produksi dengan metode MLE disajikan pada Tabel 2. Pendugaan fungsi produksi menghasilkan nilai $\mathrm{R}$ square 0.67 . Artinya bahwa sebesar 67 persen variabel bebas (input) dapat menjelaskan variabel terikatnya (output), sedangkan sebanyak 33 persen variabel terikat dipengaruhi oleh faktor lainnya. Dari 27 buah parameter dugaan diperoleh sembilan buah parameter dugaan yang secara statistik berbeda nyata dari nol.

Tabel 2 menunjukan variabel lahan dan pupuk nitrogen berpengaruh positif dan signifikan terhadap output. Hasil tersebut menunjukan bahwa meningkatnya penggunaan input (lahan dan pupuk N) akan meningkatkan produksi padi. Oleh karena itu, upaya peningkatan produksi padi dapat tercapai apabila memperhatikan pemakaian input tersebut. Hasil yang berbeda pada variabel benih yang berpengaruh negatif dan signifikan pada taraf satu persen. Artinya bahwa penggunaan benih sudah berlebih dan sesuai dengan Tabel 1 yang menunjukan bahwa rata-rata penggunaan benih sudah

Tabel 2. Hasil Pendugaan Fungsi Produksi Padi Nasional dengan Metode MLE

\begin{tabular}{|c|c|c|c|}
\hline Variabel & Estimasi & Std. Error & $z$ value \\
\hline (Intersep) & $8,4485^{* * *}$ & 0,2186 & 38,6447 \\
\hline Benih & $-0,1879 * *$ & 0,0644 & $-2,9193$ \\
\hline Pupuk N & $0,0716^{*}$ & 0,0360 & 1,9862 \\
\hline Pupuk P & 0,0163 & 0,0447 & 0,3660 \\
\hline Tenaga Kerja & 0,0479 & 0,0529 & 0,9047 \\
\hline Pestisida & $-0,0008$ & 0,0355 & $-0,0215$ \\
\hline Lahan & $0,9952^{* * *}$ & 0,1011 & 9,8481 \\
\hline 0,5 (benih) $^{2}$ & $0,0914^{* * *}$ & 0,0142 & 6,4238 \\
\hline $0,5(\text { pupuk } N)^{2}$ & 0,0065 & 0,0051 & 1,2812 \\
\hline $0,5(\text { pupuk } P)^{2}$ & 0,0048 & 0,0105 & 0,4543 \\
\hline 0,5 (tenaga kerja $)^{2}$ & $-0,0295^{*}$ & 0,0134 & $-2,2075$ \\
\hline $0,5{\text { (pestisida })^{2}}^{2}$ & $0,0135^{* * *}$ & 0,0026 & 5,1135 \\
\hline $0,5(\text { lahan })^{2}$ & $0,0605^{*}$ & 0,0276 & 2,1928 \\
\hline benih $x$ pupuk $\mathrm{N}$ & $-0,0001$ & 0,0071 & $-0,0116$ \\
\hline benih $\times$ pupuk $\mathrm{P}$ & $-0,0015$ & 0,0084 & $-0,1769$ \\
\hline benih $\mathrm{x}$ tenaga kerja & 0,0024 & 0,0095 & 0,2506 \\
\hline benih $x$ pestisida & $-0,0034$ & 0,0075 & $-0,4530$ \\
\hline benih x lahan & $-0,0441^{* *}$ & 0,0155 & $-2,8382$ \\
\hline pupuk $\mathrm{N}$ x pupuk $\mathrm{P}$ & 0,0064 & 0,0049 & 1,2956 \\
\hline pupuk $\mathrm{N} x$ tenaga kerja & $-0,0093$ & 0,0055 & $-1,6871$ \\
\hline pupuk $\mathrm{N} \times$ pestisida & $-0,0057$ & 0,0040 & $-1,4131$ \\
\hline pupuk $\mathrm{N}$ x lahan & 0,0090 & 0,0085 & 1,0553 \\
\hline pupuk $\mathrm{P} \times$ tenaga kerja & 0,0098 & 0,0066 & 1,4838 \\
\hline pupuk $\mathrm{P} \times$ pestisida & $-0,0026$ & 0,0040 & $-0,6521$ \\
\hline pupuk P x lahan & 0,0008 & 0,0106 & 0,0722 \\
\hline tenaga kerja $\mathrm{x}$ pestisida & 0,0008 & 0,0048 & 0,1581 \\
\hline tenaga kerja $x$ lahan & $-0,0274^{*}$ & 0,0128 & $-2,1399$ \\
\hline pestisida $x$ lahan & $-0,0021$ & 0,0090 & $-0,2302$ \\
\hline
\end{tabular}

Keterangan : ${ }^{* * *}$ signifikan pada taraf 0.1 persen, ${ }^{* *}$ signifikan pada taraf 1 persen, ${ }^{*}$ signifikan pada taraf 5 persen 
melebihi dari rekomendasi pemerintah. Oleh karena itu, produksi padi dapat ditingkatkan apabila petani mengurangi penggunaan benih pada komposisi tersebut (Tabel 1).

Interaksi antara lahan dan benih berpengaruh negatif dan signifikan pada taraf satu persen (Tabel 2), artinya hubungan kedua input adalah substitusi dalam peningkatan output. Studi dari Heriqbaldi (2015) menghasilkan hasil yang sama bahwa interaksi antara lahan dan benih padi di Sulawesi Selatan berpengaruh negatif dan signifikan pada taraf 5 persen. Selain itu interaksi antara tenaga kerja dan lahan juga berpengaruh negatif dan signifikan pada taraf lima persen, artinya hubungan kedua benih tersebut adalah substitusi.

Dari fungsi produksi translog tersebut dihitung elastisitas produksi masing-masing input (Tabel 3). Elastisitas produksi untuk mengukur respon produksi (output) pada setiap input. Semakin besar nilai elastisitas produksi suatu input, menunjukan produksi (output) semakin responsif terhadap input produksi. Nilai elastisitas yang negatif dalam fungsi produksi artinya penggunaan input tersebut sudah berlebih.

Hasil Tabel 1 memperlihatkan elastisitas faktor produksi padi di Pulau Jawa dan luar Pulau Jawa tidak elastis. Hal tersebut menunjukkan bahwa produksi padi pada teknologi produksi yang ada saat ini sudah tidak responsif terhadap perubahan penggunaan benih, pupuk, dan obat-obatan. Penggunaan tenaga kerja bahkan sudah berlebih.

Produksi padi paling responsif, walaupun tidak elastis terhadap lahan, baik di Pulau Jawa (0.691) maupun luar Pulau Jawa (0.734). Hal tersebut memperlihatkan bahwa setiap perluasan lahan sejumlah satu persen akan meningkatkan produksi padi sejumlah 0,691 persen di Pulau Jawa dan 0,734 persen di luar Pulau Jawa. Kusnadi et al. (2011) dan Ouedraogo (2015) menunjukan hasil yang sama.

Menarik untuk diperhatikan bahwa produksi padi di luar Pulau Jawa lebih responsif terhadap lahan dibandingkan produksi di luar Pulau Jawa. Hasil tersebut menunjukkan bahwa dengan teknologi produksi yang sama, penyediaan lahan untuk tanaman padi menjadi langkah yang paling strategis dalam meningkatkan produksi padi nasional. Hasil tersebut juga mengkonfirmasi bahwa menyediakan lahan untuk tanaman padi di luar Pulau Jawa akan lebih efektif dalam rangka meningkatkan produksi nasional dibandingkan penyediaan lahan di Pulau Jawa. Maka dari itu, dapat dikatakan bahwa peningkatan produksi padi prospektif dilakukan di luar Pulau Jawa.

Elastisitas produksi terhadap penggunaan benih, pupuk dan pestisida, menunjukan bahwa teknologi produksi di Pulau Jawa dan di luar Pulau Jawa sudah mendekati titik jenuh. Hasil analisis elastisitas produksi mengindikasikan bahwa rekayasa penggunaan input tanpa mengubah teknologi produksi padi tidak akan efektif meningkatkan produksi padi. Dalam konteks peningkatan produksi padi nasional, program intensifikasi di Pulau Jawa dan di luar Pulau Jawa bukan merupakan pilihan program yang tepat.

Input yang memiliki elastisitas paling kecil terhadap produksi padi, baik di Jawa dan luar Jawa adalah pupuk P. Artinya bahwa produksi padi paling tidak responsif terhadap penambahan pupuk P. Elastisitas produksi pupuk $\mathrm{N}$ relatif lebih besar dibandingkan pupuk P. Penelitian Novitaningrum (2019)

Tabel 3. Hasil Pendugaan Elastisitas Produksi Padi di Jawa dan Luar Jawa

\begin{tabular}{lcc}
\hline \multicolumn{1}{c}{ Variabel } & Jawa & Luar Jawa \\
\hline Lahan (ha) & 0,691 & 0,734 \\
Benih (kg) & 0,352 & 0,425 \\
Pupuk N (kg) & 0,062 & 0,057 \\
Pupuk P (kg) & 0,038 & 0,040 \\
Tenaga Kerja (HOK) & $-0,111$ & $-0,183$ \\
Pestisida (Rp .000) & 0,088 & 0,101 \\
\hline
\end{tabular}


yang dilakukan di Karanganyar, Jawa Tengah, juga menunjukan bahwa produksi padi lebih responsif terhadap pupuk $\mathrm{N}$ dibandingkan pupuk $\mathrm{P}$, walaupun kedua pupuk tersebut juga tidak elastis.

\section{EFISIENSI TEKNIS USAHATANI PADI}

Seperti telah dijelaskan pada metode, analisis efisiensi teknis pada penelitian ini menggunakan konsep efisiensi Coelli (Coelli 2005). Efisiensi menunjukkan kinerja produksi padi di level usahatani. Telah diketahui bahwa produsen utama padi di Indonesia adalah petani berlahan sempit yang dikelola dalam bentuk usahatani keluarga. Dengan demikian, Upaya peningkatan produksi padi nasional ditentukan oleh kinerja produksi sebagian besar petani produsen padi tersebut.

Pada Tabel 4 disajikan jumlah unit usahatani (petani) padi menurut selang nilai efisiensi teknis produksi. Sebagian besar $(72,92$ persen) petani padi di Jawa berada pada rentang efisiensi 0,70 sampai 0,89. Kusnadi et al. (2011) juga menjelaskan bahwa usahatani padi di Pulau Jawa lebih dominan yang efisien secara teknis dibandingkan di luar Pulau Jawa. Rata-rata efisiensi teknis produksi padi di Pulau Jawa senilai 0,72, sedangkan di luar Pulau Jawa senilai 0,61. Ini membuktikan bahwa rata-rata kinerja usahatani padi di Pulau Jawa sedikit lebih baik dibandingkan kinerja produksi padi di luar Pulau Jawa.

Efisiensi teknis bisa juga dimaknai sebagai besaran kesenjangan (gap) antara kinerja produksi yang dicapai dengan kinerja maksimum yang seharusnya dicapai. Penjelasan efisiensi di atas bisa dimaknai bahwa produksi padi di Pulau Jawa 28 persen di bawah produksi yang seharusnya, sedangkan di luar Pulau Jawa 39 persen berada di bawah produksi yang seharusnya. Gap produksi tersebut, dalam konteks peningkatan produksi padi nasional menjadi besaran potensi peningkatan produksi yang tersedia. Potensi peningkatan produksi di luar Pulau Jawa, dengan teknologi yang sama, sedikit lebih besar dibandingkan di Pulau Jawa. Peningkatan efisiensi dapat menghasilkan peningkatan produksi, apabila memperhatikan faktor-faktor yang memengaruhi efisiensi teknis usahatani padi. Faktor penentu efisiensi dibahas pada bagian selanjutnya dari tulisan ini.

Jumlah input produksi yang digunakan akan menentukan tingkat produksi padi di Indonesia. Benih, pupuk dan lahan merupakan input yang paling strategis karena pemerintah banyak mengatur kebijakan untuk ketersediaan input yang stabil dengan tepat waktu, tepat jumlah dan tepat sasaran. Input tersebut juga akan sangat menentukan keputusan petani dalam berproduksi. Selain itu, elastisitas input lahan dan benih lebih tinggi dibandingkan input lainnya. Pengaturan komposisi penggunaan input dapat menghasilkan efisiensi yang lebih tinggi. Tabel 5 menjelaskan perbedaan efisiensi produksi padi berdasarkan komposisi penggunaan input benih, pupuk nitrogen dan lahan di Jawa dan luar Jawa.

Berdasarkan Tabel 5, penelitian ini menunjukan bahwa penggunaan benih lebih dari $25 \mathrm{~kg} /$ ha memberikan efisiensi teknis usahatani yang lebih besar, baik di Jawa maupun luar Jawa. Hasil tersebut menunjukkan komposisi penggunaan benih lebih dari $25 \mathrm{~kg} / \mathrm{ha}$ akan menghasilkan efisiensi usahatani padi

Tabel 4. Sebaran Jumlah Petani Padi di Jawa dan Luar Jawa Berdasarkan Efisiensi Teknis

\begin{tabular}{cccccc}
\hline \multirow{2}{*}{ Efisiensi } & \multicolumn{2}{c}{ Jawa } & \multicolumn{2}{c}{ Luar Jawa } \\
\cline { 2 - 5 } & Jumlah Petani & Presentase (\%) & Jumlah Petani & Presentase (\%) \\
\hline$<0.50$ & 646 & 13,58 & 596 & 30,58 \\
$0.50-0.69$ & 1.603 & 33,70 & 572 & 29,35 \\
$0.70-0.89$ & 3.468 & 72,92 & 733 & 37,61 \\
$\geq 0.90$ & 344 & 7,23 & 48 & 2,46 \\
\hline Rata-Rata & & 0,72 & & 0,61 \\
Maksimal & 0,95 & & 0,93 \\
Minimal & 0,07 & & 0,06 \\
\hline
\end{tabular}


Tabel 5. Rata-rata Efisiensi Teknis Usahatani Padi Berdasarkan Komposisi Input Produksi yang Strategis

\begin{tabular}{lcccccc}
\hline \multirow{2}{*}{ Wilayah } & \multicolumn{2}{c}{ Benih (kg/ha) } & \multicolumn{2}{c}{ Pupuk N (kg/ha) } & \multicolumn{2}{c}{ Lahan (ha) } \\
\cline { 2 - 7 } & $\mathbf{5} 5$ & $\mathbf{2 5}$ & $\mathbf{5 1 7 0}$ & $\mathbf{> 1 7 0}$ & $\mathbf{5 0 , 5}$ & $\mathbf{0 0 , 5}$ \\
\hline Jawa & 0,70 & 0,72 & 0,72 & 0,71 & 0,71 & 0,74 \\
Luar Jawa & 0,57 & 0,61 & 0,59 & 0,71 & 0,62 & 0,57 \\
\hline
\end{tabular}

yang lebih tinggi. Jika dibandingkan antara Jawa dan luar Jawa, pada komposisi penggunaan benih yang sama, terlihat efisiensi produksi padi di Jawa lebih tinggi. Hal ini diduga terkait dengan kondisi agroekosistem, seperti kondisi lahan, di Jawa lebih baik dibandingkan di luar Jawa, seperti ditunjukkan pada hasil penelitian Sofyan et al. (2005) bahwa kandungan hara tanah di Jawa lebih tinggi atau sesuai untuk mendukung pertumbuhan bibit padi. Selain itu diduga karena sarana produksi di Jawa yang lebih memadai, sehingga meningkatkan efisiensi teknis.

Luas lahan juga akan memengaruhi efisiensi produksi padi. Lahan yang lebih luas cenderung akan menghasilkan efisiensi produksi yang lebih tinggi. Kondisi tersebut terjadi di Jawa, namun sebaliknya di luar Jawa (Tabel 5). Di Jawa, penggunaan lahan lebih dari 0,5 ha memiliki efisiensi produksi padi yang lebih tinggi $(0,74)$ daripada lahan $\leq 0,5$ ha. Sebaliknya di luar Jawa justru penggunaan lahan $\leq 0,5$ ha yang menghasilkan efisiensi yang lebih tinggi $(0,62)$. Kondisi ini diduga terkait erat dengan keahlian petani dalam pengelolaan lahan. Keahlian petani di Jawa lebih baik dan mampu mengelola lahan yang lebih luas sehingga menghasilkan produktivitas lahan yang lebih tinggi (Tinaprilla
2012). Hasil tersebut juga menunjukan petani di luar Jawa lebih mudah mengelola lahan yang lebih sempit, sehingga menghasilkan efisiensi teknis usahatani padi lebih lebih besar $(0,62)$. Hasil ini serupa dengan penelitian Rahman et al. (2012) yang dilakukan di Banglades menjelaskan bahwa semakin sempit ukuran usahatani (lahan), menghasilkan efisiensi teknis usahatani padi yang semakin tinggi.

\section{Faktor yang Memengaruhi Efisiensi Usahatani Padi}

Seperti sudah dijelaskan sebelumnya bahwa peningkatan produksi padi untuk mencapai produksi maksimum perlu dilakukan dengan memperhatikan beberapa faktor yang memengaruhi efisiensi produksi padi pada penggunaan input produksi tetap. Beberapa faktor yang diduga memengaruhi efisiensi dapat dilihat dari hasil estimasi model fungsi inefisensi teknis padi pada Tabel 6. Interpretasi tanda atau arah pada koefisien model inefisiensi menunjukkan pengaruh yang berlawanan terhadap efisiensi. Koefisien variabel yaitu tanda negatif artinya variabel tersebut dapat memberikan pengaruh negatif terhadap

Tabel 6. Hasil Pendugaan Fungsi Inefisiensi Teknis Padi di Indonesia

\begin{tabular}{lrrc}
\hline \multicolumn{1}{c}{ Variabel } & Koefisien & Std. Eror & $\operatorname{Pr}(>|\mathbf{z}|)$ \\
\hline Intersep & 0,2496 & 0,17 & 0,33 \\
Status pendidikan & $-0,2146^{* * *}$ & 0,03 & 0,00 \\
Kredit (\%) & $-0,0027$ & 0,00 & 0,10 \\
Dummy irigasi (1=ada, 0=tidak ada) & $-0,9612^{* * *}$ & 0,13 & 0,00 \\
Dummy status lahan (1=milik sendiri, 0=sewa) & $0,2341^{* * *}$ & 0,05 & 0,00 \\
Dummy penyuluhan (1=ikut, 0= tidak ikut) & 0,0156 & 0,71 & 0,96 \\
Dummy kelompok tani (1=gabung, 0=tidak gabung) & $-0,3174^{* * *}$ & 0,05 & 0,00 \\
Dummy bantuan (1=dapat, 0=tidak dapat) & 0,0156 & 0,71 & 0,96 \\
Dummy wilayah (1=jawa, 0=luar jawa) & $-1,0741^{* * *}$ & 0,14 & 0,00 \\
\hline SigmaSq & 1,07 & 0,14 & 0,00 \\
Gamma & 0,96 & 0,01 & 0,00 \\
\hline
\end{tabular}

Keterangan: ${ }^{* * *}$ signifikan pada taraf $\alpha=0.001$ 
inefisiensi produksi atau positif terhadap efisiensi produksi.

Tabel 6 menunjukkan variabel yang memengaruhi inefisiensi produksi padi yaitu status pendidikan, dummy irigasi, dummy status lahan, dummy kelompok tani, dan dummy wilayah. Koefisien pendidikan bertanda negatif mengartikan bahwa semakin tinggi status pendidikan petani maka menurunkan inefisiensi atau meningkatkan efisiensi produksi padi. Semakin tinggi pendidikan petani membuat petani memiliki pengetahuan wawasan lebih baik terkait teknik budidaya dan informasi lainnya sehingga mampu mengelola usahatani padi lebih baik sehingga dapat meningkatkan efisiensi usahatani padi.

Upaya peningkatan pengetahuan dan wawasan kelompok tani melalui pendidikan formal dan nonformal. Kegiatan penyuluhan pertanian, termasuk tentang usahatani padi, sudah banyak dan secara rutin dilakukan melalui kelompok tani. Petani yang aktif mengikuti kegiatan melalui kelompok tani akan memiliki pengetahuan yang lebih baik sehingga mampu mengelola usahataninya dengan baik. Hal ini juga tergambarkan dari hasil penelitian yang ditunjukkan oleh variabel dummy kelompok tani yang berpengaruh negatif signifikan. Hasil tersebut memperlihatkan bahwa petani yang menjadi anggota kelompok tani mampu mengelola usahatani padi lebih efisien daripada petani yang bukan anggota kelompok tani. Penelitian Junaedi (2016) menunjukan hal yang sama bahwa faktor pendidikan dan gabung dalam kelompok tani berpengaruh positif terhadap efisiensi usahatani padi di Jawa dan Sumatera.

Variabel dummy irigasi bertanda negatif, artinya usahatani padi pada lahan beririgasi akan memiliki efisiensi yang lebih tinggi daripada pada lahan tidak beririgasi. Irigasi yang baik berarti menjamin ketersediaan air yang cukup sehingga dapat memengaruhi kesuburan lahan dan pada akhirnya dapat meningkatkan efisiensi produksi. Nilai koefisien variabel irigasi juga paling besar dibandingkan variabel lainnya, menunjukkan bahwa irigasi sangat penting untuk ditingkatkan sebagai upaya peningkatan efisiensi produksi padi. Selain irigasi, dummy status lahan berpengaruh positif signifikan terhadap inefisiensi produksi padi. Pengelolaan usahatani padi pada lahan sewa lebih efisien dibandingkan pada lahan milik sendiri. Hal ini diduga berkaitan dengan biaya sewa lahan yang harus dikeluarkan petani. Sebagai gambaran rata-rata biaya sewa lahan di Indonesia cukup mahal yaitu sebesar Rp 3,5 juta per hektar per musim pada tahun 2017 (BPS 2019c). Hal ini akan mendorong petani penyewa untuk mengelola lahan sebaik mungkin sehingga menghasilkan produktivitas yang lebih tinggi.

Perbedaan wilayah dalam proses produksi juga memengaruhi tingkat efisiensi usahatani. Berdasarkan Tabel 4, usahatani padi yang dilakukan di Jawa lebih efisien dan mendukung dalam peningkatan produksi padi nasional. Hasil ini sesuai dengan Tabel 4 bahwa usahatani padi di Jawa lebih efisien dibandingkan di luar Jawa. Beberapa faktor yang memengaruhi, antara lain (1) rata-rata lahan Jawa memiliki sifat tanah yang lebih cocok untuk produksi padi dibandingkan di luar Jawa karena memiliki hara makro dan mikro yang lebih baik (Sofyan et al. 2005), dan (2) bantuan dan sarana prasarana produksi terkonsentrasi di Jawa (Pusdatin 2018). Namun demikian, masih rendahnya efisiensi produksi di luar Jawa juga merupakan sinyal bahwa peluang peningkatan produksi padi di luar Jawa masih cukup tinggi. Oleh karena itu upaya-upaya peningkatan faktor yang memengaruhi efisiensi produksi padi di luar Jawa perlu mendapat perhatian.

\section{KESIMPULAN DAN SARAN}

\section{KESIMPULAN}

Kesimpulan dari penelitian ini, antara lain:

1. Peningkatan produksi lahan paling besar bisa tercapai dengan perluasan lahan di luar Pulau Jawa

2. Wilayah luar Pulau Jawa memungkinkan dalam upaya peningkatan produksi padi 
nasional, melalui pengembangan teknologi produksi padi baru, karena produksi padi sudah tidak responsif terhadap penggunaan faktor produksi (input), baik di Jawa maupun di luar Jawa (inelastis).

3. Penggunaan lahan irigasi, berpendidikan tinggi, penggunaan lahan sewa dan menjadi anggota kelompok tani merupakan cara untuk memperbaiki atau meningkatkan efisiensi teknis usahatani padi untuk meningkatkan produksi padi nasional.

\section{SARAN}

1. Pemerintah dapat meningkatkan hasil produksi padi nasional dengan cara memperluas areal lahan dan meningkatkan ketersediaan jaringan irigasi.

2. Upaya peningkatan produksi padi nasional dapat ditingkatkan dengan memanfaatkan wilayah luar Pulau Jawa

3. Perubahan teknologi produksi padi yang lebih unggul diperlukan untuk meningkatkan produksi padi nasional karena produksi padi di Jawa dan luar Jawa sudah tidak responsif terhadap penggunaan faktor produksi (input).

4. Petani disarankan untuk bergabung pada kelompok tani. Kelompok tani dapat menjadi wadah peningkatan pengetahuan dan aksesibilitas petani. Oleh karena itu upaya penguatan peran kelompok tani perlu mendapat perhatian.

\section{DAFTAR PUSTAKA}

Arifin, Wahditiya AA, Nirawati, Biba MA. 2018. Efficiency And Income Of Rice Farming In Rainfed Lowland. International Journal of Scientific and Technology Research. 7(2): 52-55.

[BPS] Badan Pusat Statistika. 2017. Kajian Konsumsi Bahan Pokok 2018. Jakarta: Badan Pusat Statistika.

[BPS] Badan Pusat Statistika. 2018. Hasil Survei Pertanian Antar Sensus (SUTAS) 2018. Jakarta: Badan Pusat Statistika.
[BPS] Badan Pusat Statistika. 2019a. Perkembangan Beberapa Indikator Utama Sosial-Ekonomi Indonesia. Jakarta: Badan Pusat Statistika.

[BPS] Badan Pusat Statistika. 2019b. Luas panen dan produksi padi di Indonesia 2019 No. 16/02/Th. XXIII. https://www.bps.go.id/website/image s/KSA-2019-ind.jpg. [4 Juni 2020]

[BPS] Badan Pusat Statistika. 2019c. Nilai produksi dan biaya produksi per musim tanam per hektar budidaya tanaman padi sawah, padi ladang, jagung dan kedelai, 2017. https://www.bps.go.id/statictable/201 9/04/10/2055/nilai-produksi-danbiaya-produksi-per-musim-tanam-perhektar-budidaya-tanaman-padi-sawahpadi-ladang-jagung-dan-kedelai2017.html. [4 Juni 2020].

Christensen LR, Jorgenson DW, Lau LJ. 1973. Transcendental Logarithmic Production Frontiers. The review of economics and statistics. 55(1): 28-45.

Coelli TJ, Rao DSP, O’Donnell CJ, Battese GE. 2005. An Introduction to Efficiency and Productivity Analysis Second Edition. New York: Spinger Science and Business Media.

Heriqbaldi U, Purwono R, Haryanto T, Primanthi MR. 2015. An Analysis Of Technical Efficiency Of Rice Production In Indonesia. Asian Social Science. 11(3): 91 $-102$

Junaedi M. 2016. Efisiensi dan kesenjangan teknologi usahatani padi sawah di Indonesia: analisis meta-frontier [disertasi]. Bogor: Institut Pertanian Bogor.

Kusnadi N, Tinaprilla N, Susilowati SH, Purwoto A. 2011. Analisis Efisiensi Usahatani Padi Di Beberapa Sentra Produksi Padi Di Indonesia. Jurnal Agro Ekonomi. 29 (1):25 - 46.

Mulyani A, Kuncoro D, Nursyamsi D, Agus F. 2016. Analisis Konversi Lahan Sawah: Penggunaan Data Spasial Resolusi Tinggi Memperlihatkan Laju Konversi 
Yang Mengkhawatirkan. Jurnal Tanah dan Iklim. 40(2): 121-133.

Mulyani A, Nursyamsi D dan Syakir M. 2017. Strategi Pemanfaatan Sumberdaya Lahan Untuk Pencapaian Beras Berkelanjutan. Jurnal Sumberdaya Lahan. 11(1): 11-22.

Novitaningrum R, Supardi S, Marwanti S. 2019. Efisiensi Teknis Pengelolaan Tanaman Terpadu Padi Sawah Di Kabupaten Karanganyar, Provinsi Jawa Tengah. Jurnal Agro Ekonomi. 37(2): 123140.

Ouedraogo S. 2015. Technical And Economic Efficiency Of Rice Production In The Kou Valley (Burkina Faso): Stochastic Frontier Approach. Asian Journal of Agriculture and Rural Development. 5(2):53-63.

[Pusdatin] Pusat Data dan Sistem Informasi Pertanian. 2018. Statistik Sarana Pertanian Tahun 2018. Jakarta: Pusat Data dan Sistem Informasi Pertanian Sekretariat Jenderal - Kementerian Pertanian.

Rahman KMM, Mia MI, Alam MA. 2012. Farm Size Specific Technical Efficiency: A Stochastic Frontier Analysis for Rice Growers In Bangladesh. Bangladesh J. Agric. Econs. 35(1\&2): 131-142.

Sofyan A, Nurjana, Kasno A. 2005. Status hara tanah sawah untuk rekomendasi pemupukan.

http://balittanah.litbang.pertanian.go.id Lind/dokumentasi/buku/buku\%20laha n\%20sawah/03status_hara.pdf. [13 Mei 2020]

Tinaprilla N. 2012. Efisiensi usahatani padi antar wilayah sentra produksi di indonesia: Pendekatan Stochastic Metafrontier Production Function [disertasi]. Bogor: Institut Pertanian Bogor.

Usman MA, Widiatmaka, Firmansyah. 2019. The Land Based Food Sufficiency Model in Cirebon Regency, West Java, Indonesia. IOP Conf. Ser.: Earth Environ. Sci. doi: 10.1088/17551315/399/1/012070.
Widiatmaka, Ambarwulan W, Setiawan Y, Walter C. 2016. Assessing The Suitability and Availability of Land for Agriculture In Tuban Regency, East Java, Indonesia. Applied and Environment Soil Science. doi: http://dx.doi.org/10.1155/2016/730214 8. 